\title{
Undergraduate teaching of evolution in chile: more than natural selection
}

\author{
Enseñanza de la evolución en Chile: más que selección natural
}

\begin{abstract}
PATRICIO AHUMADA ${ }^{1}$, GUADALUPE ASTORGA ${ }^{1}$, KESTER BULL-HEREÑU $^{2}$, RICARDO CABRERA $^{1}$, LUCIANO CAPUTO $^{3}$, CARLOS CARMONA $^{1}$, M. CLAUDIA CECCHI ${ }^{2, *}$, NELSON CORTÉ $^{4}$, SOLEDAD CORTEZ ${ }^{2}$, CRISTINA DORADOR $^{5}$, FELIPE FREDES ${ }^{1}$, CARLOS GUERRERO-BOSAGNA ${ }^{2}$, PABLO HENNY $^{6}$, CAMILO LIBEDINSKY ${ }^{7}$, WARA MARCELO ${ }^{2}$, I. NATALIA MÁRQUEZ ${ }^{2}$, JAIME MARTÍNEZ ${ }^{2}$, MAURICIO MEDINA ${ }^{1}$, DANIELA PARRA ${ }^{2}$, NÉLIDA POHL ${ }^{8}$, HANS POTTSTOCK ${ }^{4}$, TOMÁS OSSANDÓN ${ }^{1}$, PABLO RAZETO $^{9}$, DAVID RUBILAR ${ }^{2}$, CARLOS SALAS $^{1}$, FERNANDA SALINAS ${ }^{2}$, ESTEBAN SEPÚLVEDA ${ }^{4}$, CAROLINA SOTO $^{1}$, RODRIGO SUÁREZ ${ }^{4}$, ALEXANDER VARGAS ${ }^{4}$, TOMÁS VEGA-ZÚNIGA ${ }^{1}$, NELSON VELÁSQUEZ ${ }^{4}$, JUAN VIDAL ${ }^{10}$, CRISTIÁN A. VILLAGRA $^{1} \&$ CAMILA P. VILLAVICENCIO ${ }^{2}$
\end{abstract}

\author{
${ }^{1}$ Departamento de Biología, Facultad de Ciencias, Universidad de Chile \\ ${ }^{2}$ Departamento de Ciencias Ecológicas, Facultad de Ciencias, Universidad de Chile \\ ${ }^{3}$ Departamento de Ecología, Facultad de Biología, Universidad de Barcelona \\ ${ }^{4}$ Instituto de Ciencias Biomédicas, Facultad de Medicina, Universidad de Chile \\ ${ }^{5}$ Max Planck Institute für Limnologie-Plön \\ ${ }^{6}$ Montreal Neurological Institute, McGill University \\ ${ }^{7}$ Department of Neurosciences, Harvard Medical School, Harvard University \\ ${ }^{8}$ Ecology and Evolutionary Biology Department, University of California Irvine \\ ${ }^{9}$ Instituto Milenio Centro de Estudios Avanzados en Biología Celular y Biotecnología CBB \\ ${ }^{10}$ LENA, Centre National de la Recherche Scientifique \\ Corresponding author: ccecchib@yahoo.com
}

In a recent commentary, Nespolo (2003) makes reference to his personal experience as exattendant to the course of evolution imparted by Dr. Humberto Maturana and Dr. Jorge Mpodozis at the Facultad de Ciencias of the Universidad de Chile to construct a negative criticism of Chilean undergraduate teaching of evolution. As ex-attendants of the mentioned course of evolution we have had an experience that is directly comparable to that of Dr. Nespolo. Here we wish to point out our opinion regarding this course, which is markedly different. First, it is a caricature to state that in this course natural selection is taught as being wrong. A serious and critical revision of natural selection, the synthetic theory, and evolutionary ecology is a fundamental part of the course. These and other topics are presented by researchers from those fields, such as Drs. Germán Manríquez and Rodrigo Medel. The scientific contributions of both researchers receive positive comments in Nespolo (2003).

Second, in order to asses whether the aforementioned course is biased towards insufficient teaching of natural selection, it is enlightening to carry out a brief overview of the time dedicated to this topic and the microevolutionary approach in this and other courses at Chile, USA and Europe. We reviewed the topics taught in six different courses and expressed the percentage of the time, from the total of classes, allocated to those topics (Table 1). We found that there is no evidence to claim that in the course of evolution imparted at the University of Chile, alternative historical-structural approaches such as natural drift (Maturana \& Mpodozis 2000) are taught at the expense of other classical topics in evolution.

Third, natural drift (Maturana \& Mpodozis 2000) is not taught as a dogma. The epistemological aspects behind theories are studied and discussed as well as experimental and theoretical approaches that may or may not support the theory of evolution by natural drift. Nespolo (2003) considered natural drift to be taught as dogma under the argument that it can not be submitted to falsification. However, the same argument is applicable to natural selection because no crucial experiment or case can be defined to prove that the theory of evolution by natural selection is incorrect (Popper 1976). Such an approach is inadequate when discussing the complex historical phenomenon of the evolution of life on earth. (Mayr 1998). Rather, the general conceptual 
framework for evolution can be contrasted with several different sources of empirical observations. In evolutionary biology, empirical observations of natural phenomena and experimental results constitute the logical prediction, or facts consistent with a particular theory (Mayr 1998). For example, measurements of heritability and cases of artificial selection have been argued to be consistent with natural selection (Nespolo 2003), whereas epigenetic plasticity and neutral genetic change have been argued to be more consistent with natural drift (Maturana \& Mpodozis 2000).

In the context of natural drift, explanation of evolution is attempted without invoking any mechanism or force that is not readily observable in the natural world. It is therefore very odd that Nespolo (2003) made a comparison between the antievolutionist movement in education in the United States and the undergraduate teaching of organic evolution in Chile. Teaching or discussing natural drift does not lead to antievolutionism, a prescientific level that is the absolute opposite to what occurs in the undergraduate courses we know of.

Fourth, it is important for undergraduate teaching of evolution to include the actual diversity of different approaches and explanatory mechanisms posed to explain organic evolution, without assuming that natural selection must have a central role. Moreover, we find it convenient to discuss the epistemological foundations that underlie scientific theories, especially so in evolutionary biology. Finally, we think that a formal discussion of evolution through natural selection or natural drift is legitimate and necessary. However, Nespolo (2003) should have communicated his ideas restricting himself to the scientific aspects involved, without using expressions such as "dogmatism" and "lack of knowledge" to refer to the thinking and teaching of his colleagues. These are, in fact, personal judgments that do not collaborate to a constructive discussion of these topics.

\section{LITERATURE CITED}

MATURANA-ROMESIN R \& J MPODOZIS (2000) The origin of species by means of natural drift. Revista Chilena de Historia Natural 73: 261-310.

NESPOLO RF (2003) Evolution by natural selection: more evidence than ever before. Revista Chilena de Historia Natural 76: 699-716.

POPPER K (1976) El darwinismo como programa metafísico de investigación. Tercera edición. Tecnos, Madrid, España. 320 pp.

MAYR E (1998) Así es la biología. Editorial Debate, Madrid, España. 326 pp.

TABLE 1

Percentage from total lectures per course allocated to microevolutionary processes and natural selection lectures for undergraduate courses from six universities around the world. Microevolution and natural selection percentage includes quantitative genetics, adaptation, evolutionary ecology,

behavioral ecology and coevolution lectures. All this information is available online at the universities web pages

Porcentaje de clases por curso destinadas a la enseñanza temática de microevolución y selección natural para cursos de pregrado de seis universidades alrededor del mundo. El porcentaje destinado a microevolución y selección natural incluye tópicos como genética cuantitativa, adaptación, ecología evolutiva, ecología conductual y coevolución. La información original está disponible en las páginas web de cada una de las universidades mencionadas

\begin{tabular}{llcc}
\hline Country & Institution & Lectures & Microevolution and natural selection (\%) \\
\hline Chile & Universidad de Chile & 25 & 28.0 \\
Chile & Pontificia Universidad Católica de Chile & 14 & 28.6 \\
USA & Harvard University & 25 & 8.0 \\
USA & New York University & 25 & 32.0 \\
France & Université Catholique de Louvain & 30 & 6.7 \\
UK & University of Cambridge & 60 & 48.3 \\
\hline
\end{tabular}

